\title{
Influence of edible coatings and storage duration on post-harvest performance of plum
} \author{
Syed Tanveer Shah ${ }^{1}$, Abdul Basit ${ }^{1}$, Inayat Ullah ${ }^{2}$, Muhammad Sajid ${ }^{1}$,
} Imran Ahmad ${ }^{1}$, Intizar Ahmad ${ }^{1}$, Muhammad Areeb Khalid ${ }^{1}$, Sanaullah $^{3 *}$, Izhar Ullah ${ }^{4}$ and Bashir Muhammad ${ }^{1}$

1. Department of Horticulture, Faculty of Crop Production Sciences, The University of Agriculture, Peshawar, 3125-Pakistan

2. Department of Agricultural Mechanization, The University of Agriculture, Peshawar-Pakistan

3. Department of Agricultural Extension Education and Communication, The University of Agriculture, Peshawar-Pakistan

4. Department of Horticulture, Ondokuz Mayis University, 55200, Samsun-Turkey

*Corresponding author's email: sanaullah9224@gmail.com

Citation

Syed Tanveer Shah, Abdul Basit, Inayat Ullah, Muhammad Sajid, Imran Ahmad, Intizar Ahmad, Muhammad Areeb Khalid, Sanaullah, Izhar Ullah and Bashir Muhammad. Influence of edible coatings and storage duration on post-harvest performance of plum. Pure and Applied Biology. Vol. 10, Issue 1, pp81-96.

http://dx.doi.org/10.19045/bspab.2021.100010

\begin{tabular}{llll}
\hline \hline Received: $15 / 06 / 2020$ & Revised: 24/08/2020 & Accepted: 02/09/2020 & Online First: 15/09/2020 \\
\hline \hline
\end{tabular}

\section{Abstract}

Regulation of loss in fruit weight is mainly occurred due to metabolic activities, respiration and transpiration. Postharvest quality and extending shelf life of horticultural crops is mainly concerned with maturity indices and edible coating materials which are significantly good and safe for health. Therefore, an experiment was performed to know the influence of various coating materials and storage duration on plum cv. Fazl-i-manani at Postharvest Horticulture laboratory, The University of Agriculture, Peshawar-Pakistan. Castor oil coated plum fruits sustained the maximum titratable acidity (\%), ascorbic acid content $\left(\mathrm{mg} .100 \mathrm{~g}^{-1}\right)$, juice content $(\%)$, color, taste and aroma score, with the lowest total soluble solids ( $\left.{ }^{0} \mathrm{Brix}\right), \mathrm{pH}$ and weight loss (\%). On the contrary, the highest titratable acidity (\%), ascorbic acid content (mg.100g $\mathrm{g}^{-}$ ${ }^{1}$ ), firmness $\left(\mathrm{Kg} \mathrm{cm}^{-2}\right)$, juice content (\%), minimum weight loss $(\%)$, total soluble solids $\left({ }^{0} \mathrm{Brix}\right)$, decay $(\%)$ and $\mathrm{pH}$ were recorded in storage at 0 day. The maximum weight loss $(\%)$, total soluble solid ( ${ }^{0}$ Brix), decay incidence $(\%)$ and $\mathrm{pH}$, with least titratable acidity $(\%)$, ascorbic acid content $\left(\mathrm{mg} .100 \mathrm{~g}^{-1}\right)$, juice content $(\%)$, color, aroma and taste were witnessed in those fruits which were stored for 28 days. In conclusion, it is proposed that plum fruits should be coated with castor oil for sustaining its quality aspects for extended time.

Keywords: Climacteric fruit; Edible Coating; Perishability; Prunus domestica L.; Shelf Life Introduction

In contrast to many commodities, vegetables and fresh fruits proceeds to respire after it's harvesting. It takes $\mathrm{O}_{2}$ and releases water vapors and $\mathrm{CO}_{2}$. For keeping these commodities fresh, it is important to lower the rate of respiration without damaging the product quality. The respiration rate could be lowered by reduced level of $\mathrm{O}_{2}$, low temperature and optimum concentration of $\mathrm{CO}_{2}$ [1]. Plum fruit (Prunus domestica L.) comes in deciduous group of fruits generally called as stone fruit. In Pakistan, it is a major fruit and it is cultivated in temperate areas mostly but few lowered chilling cultivars 
can be cultivated in the sub-tropical milder regions of Khyber Pakhtunkhwa and some parts of Balochistan like Qallat and Quetta [2]. The magnitude of post-harvest losses is subject to variation from time to time and country to country [3]. Post-harvest losses were $23 \%$ on the average for different varieties of peach in Swat [4]. The scarcity of storage and transportation resulted in $25-40 \%$ post-harvest losses in Pakistan [5].

Several post-harvest procedures i.e. wax emulsion, edible coating, oil coating, chemical application, growth regulators, use of fungicide, calcium treatment; low temperature storage and other various types of packaging materials are made to prolong the fruit's shelf life after harvest and prevent reduction in quality $[6,7]$. Application of edible coatings is one of the most environment friendly technologies used for minimizing moisture loss, oxidation processes or gases exchange, improve quality and shelf life of fruits [8]. Practice of coating materials is one of the important methods to increase the postharvest life of vegetables and fruits. Edible coatings act and develop a micro condition, resultantly lower the changes in quality and reduce the losses in quality [9]. Coating material provides an atmosphere that is modified by keeping a semi permeable blockage versus oxygen, moisture, solute movement and carbon dioxide which reduces the rates of respiration, loss of water and reactions involving oxidation [10]. Coating reduces loss of water, respiration, retains flavor, maintains texture and inhibits pathogen attack in fruits and thus increases postharvest life. Edible coatings are important because these coatings are not synthesized chemically rather they are natural products and are developed by natural ways [11]. The good storage coating materials are edible oils for fresh produce and it has least side effects on health of humans. Ideal coating is the one which can extend the shelf life of fresh fruits without triggering an-aerobiosis and which without affecting the quality of the fruit inhibits decay [12]. In Pakistan, Nepal and India food commodities are protected by castor oil application for extended storage, inhibiting mold formation and rotting process [13]. Aloe era gel coatings have been found to inhibit moisture loss and firmness, regulate rate of respiration and maturation development. It also reduces the proliferation of microorganisms and delays browning by oxidation in cherries [14]. Edible coating over fruits and vegetables are used to improve their quality and shelf life $[15,16]$. Edible coatings are used for extension of shelf life of fruits and vegetables and they can also be safely eaten as part of the product and do not add unfavorable properties to the foodstuff [17]. Edible coatings have good gas barrier and moisture barrier properties best suitable for post-harvest management [18]. The main characteristic feature of edible coating is to increase shelf life of fresh or processed fruits and vegetables and it is protected from postharvest damages and environmental damages [19]. Therefore, current research was planned to explore the efficiency of edible coating materials in sustainability after harvest. To discover the best one among all coating materials for extending storage life of plum fruit with minimum post-harvest losses. Evaluation of the shelf life of plum fruit under refrigerated conditions. To study the interaction between different types of coating material and storage time for fruit quality and post-harvest performance of plum.

\section{Materials and Methods}

\section{Experimental site and procedure}

The present research study was conducted in Horticultural Laboratory, The University of Agriculture Peshawar, located at 34.01o $\mathrm{N}$ latitude, $71.35 \mathrm{o} \mathrm{E}$ longitude at an altitude of $350 \mathrm{~m}$ above sea level in Peshawar valley with sub-tropical climate [20]. Peshawar is located about $1600 \mathrm{~km}$ north of the Indian Ocean. The research farm is irrigated by Warsak canal from river Kabul [21]. Both the summer 
and winter weather are extreme [22], characterized by severe winter and prolonged hot summer, where the average minimum temperature during winter is $5^{0} \mathrm{C}$ and maximum up to $47^{\circ} \mathrm{C}$ during summer. The wettest month (with the highest rainfall) is March $(78 \mathrm{~mm})$, and driest month (with the lowest rainfall) is June ( 7 $\mathrm{mm}$ ) approximately. The selected plums were harvested when they were physiologically mature. After harvesting, the samples were brought into Postharvest Laboratory of the Department of Horticulture, at The University of Agriculture, Peshawar. The distilled water was used to wash the fruits in order to remove the dust particles and residues were applied edible coatings and kept at refrigerated condition $\left(8^{0} \mathrm{C}\right)$. Fruits were then covered in newspaper used as a standard packaging material. The research experiment was executed using Complete Randomized Design (CRD) with two factors and three replications. The experiment consisted of edible coatings $\left(\mathrm{E}_{1}=\right.$ Control with no coating material, $\mathrm{E}_{2}=$ Glycerin, $\mathrm{E}_{3}=$ Aloe Vera Gel, $\mathrm{E}_{4}=$ Almond oil and $\mathrm{E}_{5}=$ Castor oil) and storage durations $\left(S_{1}=0, \quad S_{2}=7, \quad S_{3}=14\right.$, $\mathrm{S}_{4}=21$ and $\mathrm{S}_{5}=28$ days). Aloe Vera gel available in the market has a very low quantity of actual aloe vera and other unwanted materials in a large amount. That's why the gel was extracted at laboratory to get perfectly pure and organic, and natural gels as coating materials. For this purpose the aloe vera leaves (4-5) were taken from Ornamental nursery, The University of Agriculture Peshawar and washed up. The leaves were peeled with sharp knife and removed the gel with table spoon into the blender directly. Then, blended the slices and removed the green chunks (leaf tissues), and the pure aloe vera gel was then placed in a clean and sterilized jar.

\section{Parameters studied}

\section{Fruit weight Loss (\%)}

Samples of fresh fruits were weighed by using a digital balance (Shimadzu, model
AY220). Reading initially was deducted from fruit weight of last reading taken before 7 days to check the weight loss. For calculating weight loss, the formula used was as follows;


Reading (Initial)

\section{Total soluble solid ( $\left.{ }^{0} \mathrm{Brix}\right)$}

A standard method of [23] was used to calculate total soluble solid (TSS) using a handhold refractometer after juice extraction. A drop of extracted juice (from separate fruit) was spotted on spotless and dry prism of refractometer and led was closed properly [24]. Fruit drops were used to be kept on the prism and recorded the data.

\section{Disease or decay incidence $(\%)$}

After an interval of each seven days the diseased fruits were observed and recorded for data. For convenience, formula is given below for computing the percent disease incidence.

$$
\begin{aligned}
\text { Disease incidence }(\%) & =\text { No. of decayed fruits } \\
\text { Total number of fruits } & 100
\end{aligned}
$$

\section{Titratable acidity (\%)}

In order to calculate the titratable acidity in percent, [25] standard procedure was used. Sample of $10 \mathrm{ml}$ grapefruit juice were chosen and then diluted to the desired point in volumetric flask of $100 \mathrm{ml}$.Subsequently, $10 \mathrm{ml}$ of the obtained diluted sample was taken in a titration flask and 2-3 drops of phenolphthalein as an indicator were added and finally titrated against $0.1 \mathrm{~N} \mathrm{NaOH}$ solutions till the time of appearance of light pink color. Recorded titratable acidity was calculated by using the following formula;

Acidity (\%) $=\underline{\text { N X T X F X } 10} \times 100$

$$
\text { DXS }
$$

Whereas:

$\mathrm{N}=\mathrm{NaOH}-$ Normality

$\mathrm{T}=0.1 \mathrm{~N} \mathrm{NaOH}$ taken in milliliter $(\mathrm{ml})$

$\mathrm{F}=$ Acid factor (Constant 0.0067 -Citricacid)

$\mathrm{D}=$ Sample weight $(\mathrm{ml})$ used in dilution $\mathrm{S}=$ Diluted sample $(\mathrm{ml})$ used in titration

\section{Ascorbic acid content (mg. $100 \mathrm{~g}^{-1}$ )}

For the ascorbic acid content determination, Dye method as described 
by [26] was used. A $10 \mathrm{ml}$ of juice was selected from the extracted fruit using pipette and it was added to the graduated cylinder. To make $10 \%$ solution, the volume was elevated to $100 \mathrm{ml}$ level with the help of oxalic acid solution. From the burette, which encompassed dye (50 $\mathrm{mg}$ of 2-6 dichloro-phenol indo phenol $+42 \mathrm{mg}$ baking soda), $10 \%$ solution was taken for titration and the titration process continued till time as pink color was reached. The following formula was used to calculate the observed readings of Vitamin-C.

Ascorbic Acid $\left(\mathrm{mg}^{100 \mathrm{~g}^{-1}}\right)=\underline{\mathrm{F} \mathrm{X} \mathrm{T} \mathrm{X} 100} \times 100$ DXS

$\mathrm{N}=\mathrm{NaOH}$ Normality
$\mathrm{T}=$ Solution (Dye) taken for the burette (mm)

$\mathrm{F}=$ Dye-factor

$\mathrm{S}=$ Fruit juice $(\mathrm{g})$ used in dilution

$\mathrm{D}=$ Diluted sample used for titration $(\mathrm{mm})$ pH of fruit juice

$\mathrm{pH}$ of fruit juice which was taken from randomly chosen fruits was measured using an electronic $\mathrm{pH}$ meter in each replication, while inserting in to the fruit juice.

Juice content (\%)

Percent juice content was taken by weighing the juice extracted from each single weighed plum fruit. The juice content was then calculated with the help of the following formula [27].

\section{$\%$ Juice content $=\underline{\text { Weight } \text { of single fruit }- \text { Weight of juice extracted }} \times 100$ Weighted fruits}

\section{Fruit Firmness (Kg.cm-2)}

Penetrometer (Model-Wanger FT-37) was used to record fruit firmness with a capability of 28 pounds (lbs).

\section{Organoleptic evaluation}

For the organoleptic-evaluation, taste, aroma and visual quality was estimated according to 10 points hedonic scale with 10 being the best for fruit taste, texture and physical appearance.

\section{Statistical analysis}

The obtained data were analyzed using variance (ANOVA) which is suitable for Completely Randomized Design (CRD using Statistics software package (Statistix 8.1, Analytical software Inc., USA) as suggested by [28]. The means were tested with probability of least significant difference (0.01).

\section{Results}

\section{Weight loss (\%)}

Data regarding weight loss showed significant difference on coatings, storage duration and their interaction (Table 1). Maximum weight loss i.e. $15.11 \%$ was observed in untreated fruits followed by almond oil (14.46\%). Whereas, the minimum fruit weight loss that is $13.13 \%$ was noted in castor oil treated fruits. The fresh fruits weighted initially showed no weight loss $(0 \%)$ while weight loss $(21.09 \%)$ after 21 days was observed in stored fruits. Whereas, the highest weight loss $(27.18 \%)$ was seen after 28 days of storage. Data regarding interaction also observed no weight loss $(0 \%)$ in the fruits with treated and untreated as well, where the highest $(30.05 \%)$ was recorded in control treatment stored for 28 days (Fig. $1)$.

\section{Total soluble solid ( ${ }^{0}$ Brix)}

Coating materials, storage durations as well as their interaction affected the TSS $\left({ }^{0}\right.$ Brix) of plum fruit significantly (Table 1). Maximum $\operatorname{TSS}\left(9.30^{\circ}\right.$ Brix $)$ was recorded in untreated fruits followed by $\left(8.93^{\circ}\right.$ Brix) in almond oil treated fruits, while those fruits which were treated with castor oil, showed the lowest TSS $\left(8.49^{0} \mathrm{Brix}\right)$. For storage duration, the plum fruits that were stored for 28 days, maximum TSS ( $9.34{ }^{0}$ Brix) was noticed in them, followed by storage duration of 14 days with TSS $\left(8.95^{\circ}\right.$ Brix). However, in case of fresh fruits, the minimum value recorded was TSS (8.34 ${ }^{0}$ Brix). Maximum TSS $\left(9.90{ }^{0}\right.$ Brix) was observed in those fruits which were untreated and were 
stored for time of 28 days with the interaction of storage time duration and edible coatings. Moreover, minimum TSS $\left(8.08^{0}\right.$ Brix $)$ was observed for fruits that were treated with castor oil in storage duration of 28 days (Fig. 2).

Table 1. Weight loss, total soluble solid, decay incidence, titratable acidity and fruit juice $\mathrm{pH}$ of plum fruit as affected by edible coatings and storage duration

\begin{tabular}{|c|c|c|c|c|c|c|}
\hline $\begin{array}{l}\text { Coating } \\
\text { Materials }\end{array}$ & $\begin{array}{l}\text { Weight } \\
\text { loss (\%) }\end{array}$ & $\begin{array}{c}\text { TSS }\left({ }^{\circ} \text { Brix }\right) \\
(\%)\end{array}$ & $\begin{array}{c}\text { Decay } \\
\text { incidence } \\
(\%)\end{array}$ & $\begin{array}{l}\text { Titratable } \\
\text { acidity } \\
\left(\mathbf{m g . 1 0 0 g}^{-1}\right)\end{array}$ & $\begin{array}{c}\text { Ascorbic } \\
\text { acid }\end{array}$ & $\begin{array}{c}\text { Fruit } \\
\text { juice pH }\end{array}$ \\
\hline Control & $15.11 \mathrm{a}$ & $9.30 \mathrm{a}$ & $11.11 \mathrm{a}$ & $0.66 \mathrm{~d}$ & $5.59 \mathrm{~d}$ & $4.23 \mathrm{a}$ \\
\hline Glycerin & $13.90 \mathrm{c}$ & $8.66 \mathrm{~d}$ & $8.88 \mathrm{ab}$ & $0.70 \mathrm{~b}$ & $6.19 \mathrm{c}$ & $4.09 \mathrm{~d}$ \\
\hline Aloe vera Gel & $13.80 \mathrm{c}$ & $8.77 \mathrm{c}$ & $2.22 \mathrm{c}$ & $0.70 \mathrm{~b}$ & $6.22 b$ & $4.12 \mathrm{c}$ \\
\hline Almond oil & $14.46 \mathrm{~b}$ & $8.93 \mathrm{~b}$ & $4.44 \mathrm{bc}$ & $0.68 \mathrm{c}$ & $6.20 \mathrm{bc}$ & $4.15 b$ \\
\hline Castor oil & $13.13 \mathrm{~d}$ & $8.49 \mathrm{e}$ & $2.22 \mathrm{c}$ & $0.73 \mathrm{a}$ & $6.57 \mathrm{a}$ & $3.98 \mathrm{e}$ \\
\hline LSD $\leq 0.05$ & 0.54 & 0.05 & 6.46 & 0.009 & 0.03 & 0.02 \\
\hline \multicolumn{7}{|c|}{ Storage duration (days) } \\
\hline $\mathbf{0}$ & $0.00 \mathrm{e}$ & $8.34 \mathrm{e}$ & $0.00 \mathrm{~b}$ & $0.79 \mathrm{a}$ & $7.61 \mathrm{a}$ & $2.94 \mathrm{e}$ \\
\hline 7 & $7.99 \mathrm{~d}$ & $8.82 \mathrm{c}$ & $0.00 \mathrm{~b}$ & $0.72 b$ & $7.16 \mathrm{~b}$ & $3.36 \mathrm{~d}$ \\
\hline 14 & $14.14 \mathrm{c}$ & $8.95 \mathrm{~b}$ & $0.00 \mathrm{~b}$ & $0.70 \mathrm{c}$ & $6.34 \mathrm{c}$ & $3.78 \mathrm{c}$ \\
\hline 21 & $21.09 \mathrm{~b}$ & $8.71 \mathrm{~d}$ & $4.44 \mathrm{~b}$ & $0.66 \mathrm{~d}$ & $5.35 \mathrm{~d}$ & $4.60 \mathrm{~b}$ \\
\hline 28 & $27.18 \mathrm{a}$ & $9.34 \mathrm{a}$ & $24.44 \mathrm{a}$ & $0.59 \mathrm{e}$ & $4.32 \mathrm{e}$ & $5.88 \mathrm{a}$ \\
\hline $\mathrm{LSD} \leq 0.05$ & 0.54 & 0.05 & 6.46 & 0.009 & 0.03 & 0.02 \\
\hline \multicolumn{7}{|c|}{ Interaction } \\
\hline
\end{tabular}

Note: Means followed by dissimilar letters differ from each other by $5 \%$ probability level

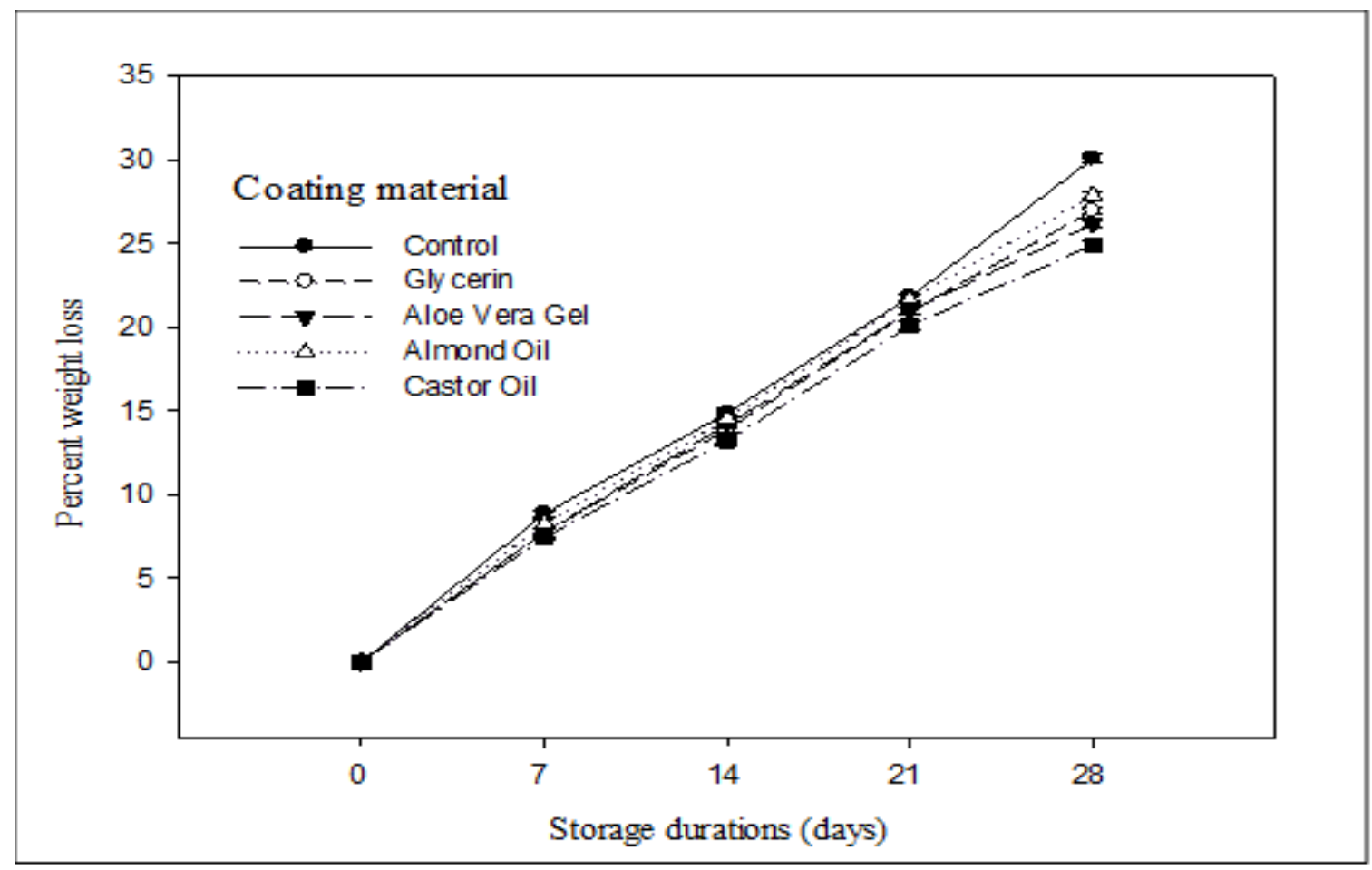

Figure 1. Weight loss of Plum fruit as affected by interaction of edible coatings and storage durations 


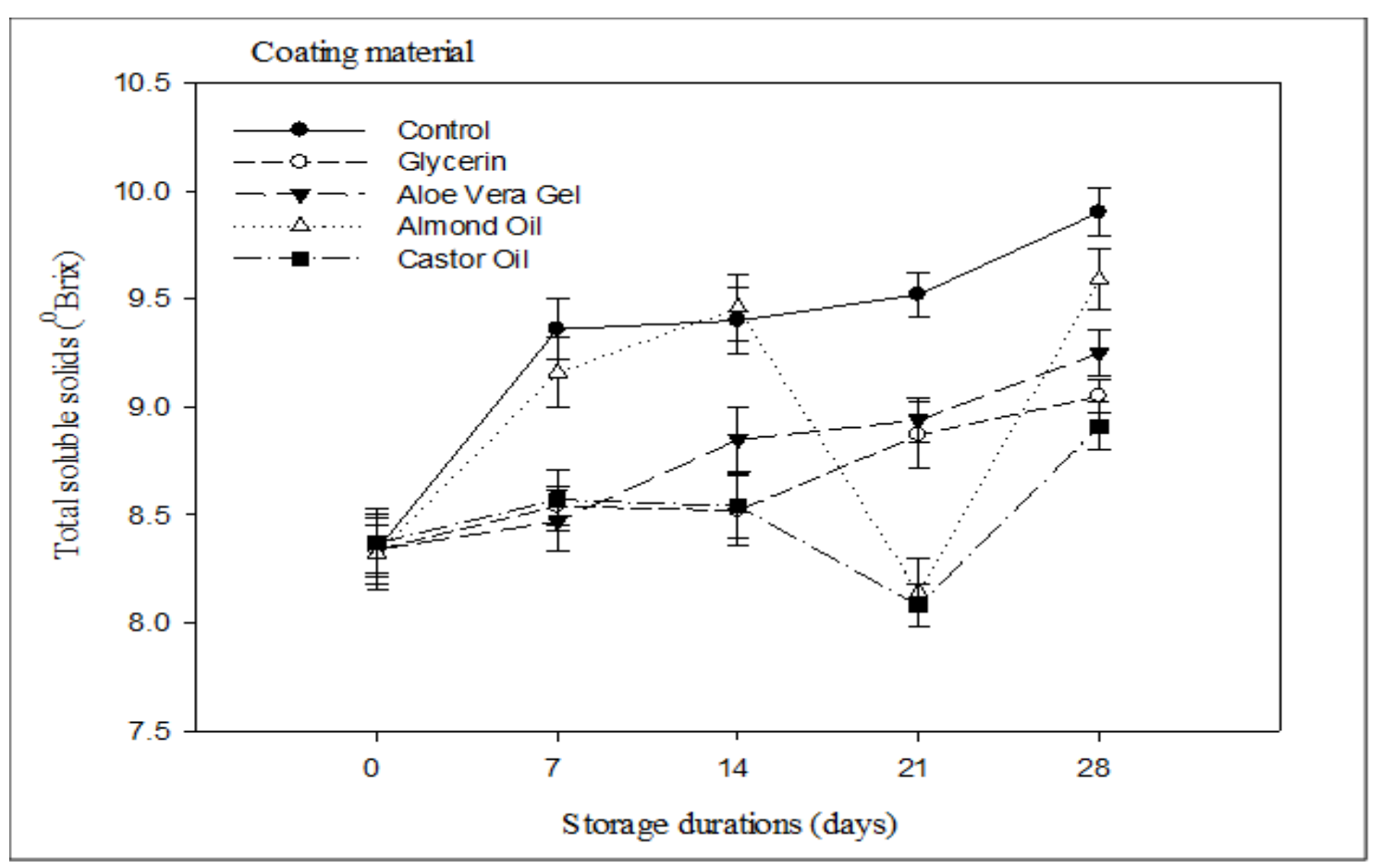

Figure 2.Total soluble solid of Plum fruit as affected by interaction of edible coatings and storage durations

\section{Decay incidence (\%)}

Data regarding storage durations and coating materials showed significant effect on decay incidence in plum fruits, whereas, interaction for storage and coating was found non-significant (Table 1). Data regarding coating materials showed that the maximum decay incidence $(11.11 \%)$ was recorded in untreated fruits (control), followed by glycerin ( $8.88 \%$ ) and aloe vera gel treated fruits gave almond oil (4.44\%). However, fruits treated with aloe vera gel and castor oil showed less decay incidence i.e. 2.22\%. Whereas, data regarding storage showed that fruits stored for 28 days illustrated the highest decay incidence $(24.44 \%)$, followed by $(4.44 \%)$ in those fruits which were stored for 21 days. However, fruits stored at 0,7 and 14 days both untreated and treated fruits didn't observe any decay incidence.

\section{Titratable acidity $(\%)$}

Data presented in (Table 1) regarding coating depicted that maximum titratable acidity was $(0.73 \%)$ recorded in castor oil treated plums, following $(0.70 \%)$ in plums coated with glycerin and aloe era, however, a minimum titratable acidity i.e. $0.66 \%$ was recorded for untreated fruits. Similarly, with the increase in storage for plums, titratable acidity was decreased. Maximum titratable acidity $(0.79 \%)$ observed in 0 day fruits following $(0.72 \%)$ of 7 days stored plums. However, lowest titratable acidity $(0.59 \%)$ observed in 28 days stored plums. The findings regarding interaction revealed that untreated fruits on storage were found with the most decreased titratable acidity. The highest titratable acidity $(0.80 \%)$ was observed on storage duration of 0 day in both control as well as in fruits that were treated with castor oil. Though, on 28 days duration of storage, untreated fruits showed the lowest titratable acidity i.e. $0.53 \%$ (Fig. 3).

\section{Ascorbic Acid content (mg.100g-1)}

The storing interval, coatings and its interaction presented in (Table 1) showed a positive effect on the content of ascorbicacid obtained from plum fruits. In case of coating, highest value of ascorbic-acid 
that is $6.57 \mathrm{mg} .100 \mathrm{~g}^{-1}$ was recorded in fruits treated with castor oil followed by ascorbic-acid having value of 6.22 mg. $100 \mathrm{~g}^{-1}$ of aloe era gel covered fruits, while in control plums, least ascorbic-acid i.e. $\quad 5.59 \mathrm{mg} .100 \mathrm{~g}^{-1}$ ) were recorded. Concerning storing interval it was declared that with increasing storing interval, ascorbic-acid content was minimized. The higher content of ascorbic-acid (7.61 $\mathrm{mg} .100 \mathrm{~g}^{-1}$ ) was noted in fresh plums, followed by those fruits which were kept at duration of 7 days with ascorbic-acid value of $7.16 \mathrm{mg} .100 \mathrm{~g}^{-1}$. Furthermore, for 28 days stored plums, the least ascorbicacid value i.e. $4.32 \mathrm{mg} .100 \mathrm{~g}^{-1}$ was observed. Results referring interaction showed the highest content ascorbic-acid (7.64 mg. $\left.100 \mathrm{~g}^{-1}\right)$ recorded in almond oil covered plums stored for 0 days, whereas the lowest content ascorbic-acid (3.19 mg. $\left.100 \mathrm{~g}^{-1}\right)$ noted in plums that were untreated for 28 days (Fig. 4).

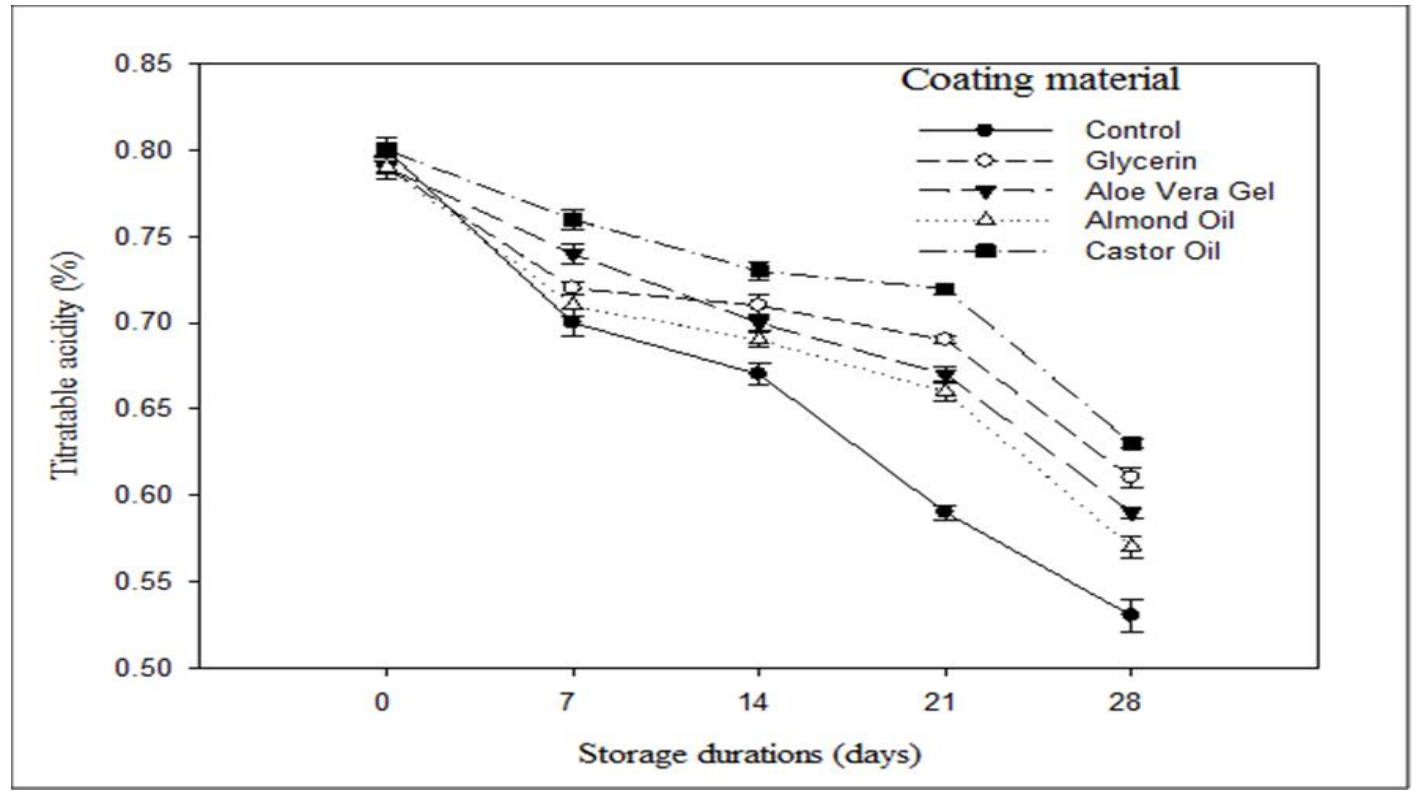

Figure 3. Titratable acidity of Plum fruit as affected by interaction of edible coatings and storage durations

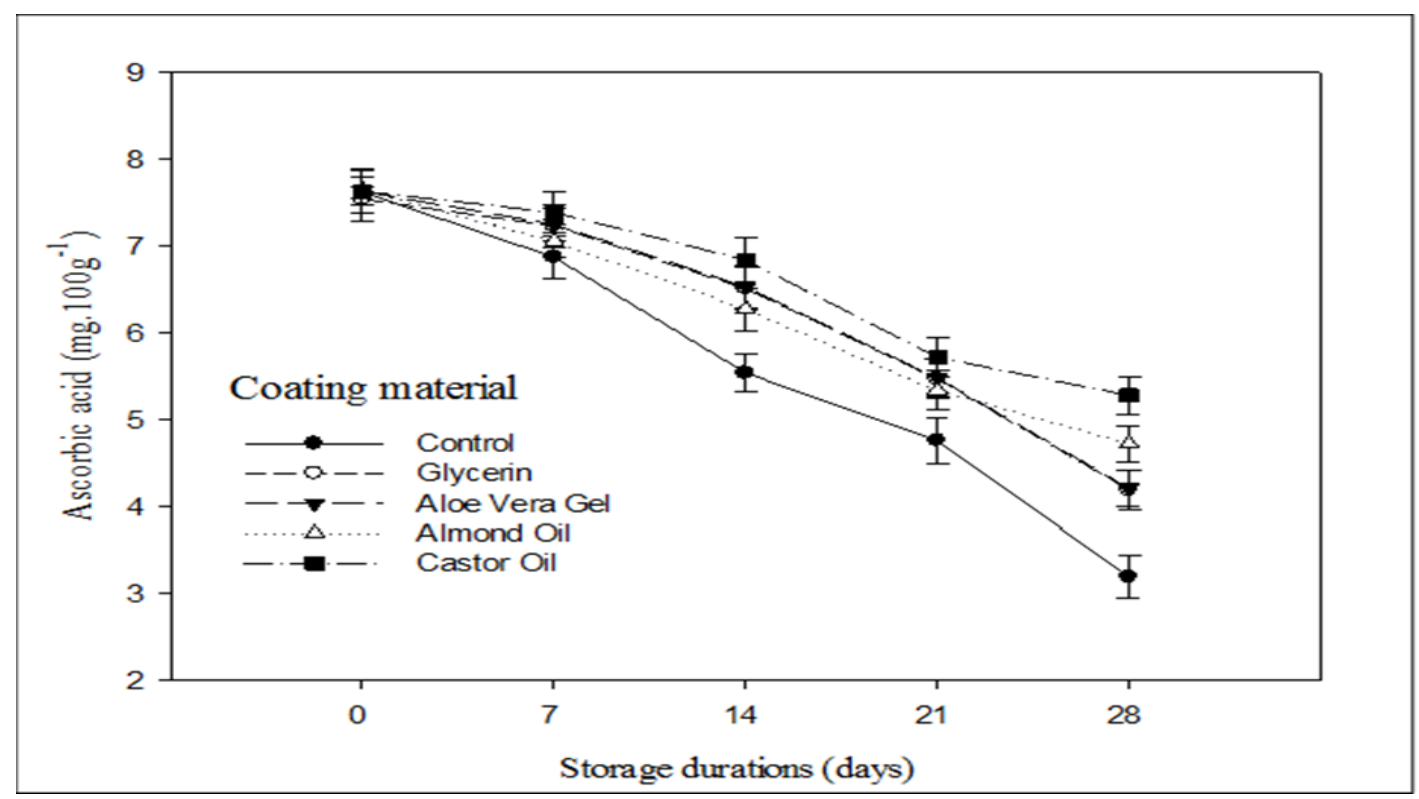

Figure 4. Ascorbic acid of Plum fruit as affected by interaction of edible coatings and storage durations 
pH of fruit juice

Variation of $\mathrm{pH}$ for plum fruit juice was observed during storage durations at maturity stage, where it was affected by different coating materials, storage durations and its interactive results (Table 1). Mean table data showed that the maximum $\mathrm{pH}$ (4.23) recorded in control plums, following by fruit juice $\mathrm{pH}$ (4.15) coated with almond oil, whereas the least $\mathrm{pH}$ (3.98) noted in castor oil coated plums. Mean data regarding storing periods indicated that with increasing storage duration $\mathrm{pH}$ of the fruits also increases. Highest value of $\mathrm{pH}(5.88)$ recorded at 28 days, following (4.60) at 21 days, whereas lowest $\mathrm{pH}$ (2.94) was observed at first day. The data of interaction disclosed that at fresh date, all fruits' $\mathrm{pH}$ were almost the same statistically. The results showed that higher $\mathrm{pH}$ (6.10) recorded in control plums at 28 storing day, whereas the least $\mathrm{pH}$
(2.93) observed in plums covered by aloe era gel at 0 storing day (Fig. 5).

Juice content (\%)

Data presented in (Table 2) shows that coating materials and storing durations have significant effect on percent content of plums juice, while interaction of storage and coatings was found non-significant. Regarding coatings, maximum content of juice $(63.40 \%)$ was in plums covered by castor oil following content of juice $(59.53 \%)$ noted in plums covered with glycerin, whereas least content of juice $(57.60 \%)$ was recorded in control plums. In storage durations data it was disclosed that content of juice declined with prolonging storing interval. Juice content data was also significantly affected by storing intervals. Desirable content of juice $(82.06 \%)$ noted at 0 day following content of juice $(73.46 \%)$ at 7 days, while least content juice $(32.73 \%)$ recorded at 28 storing day.

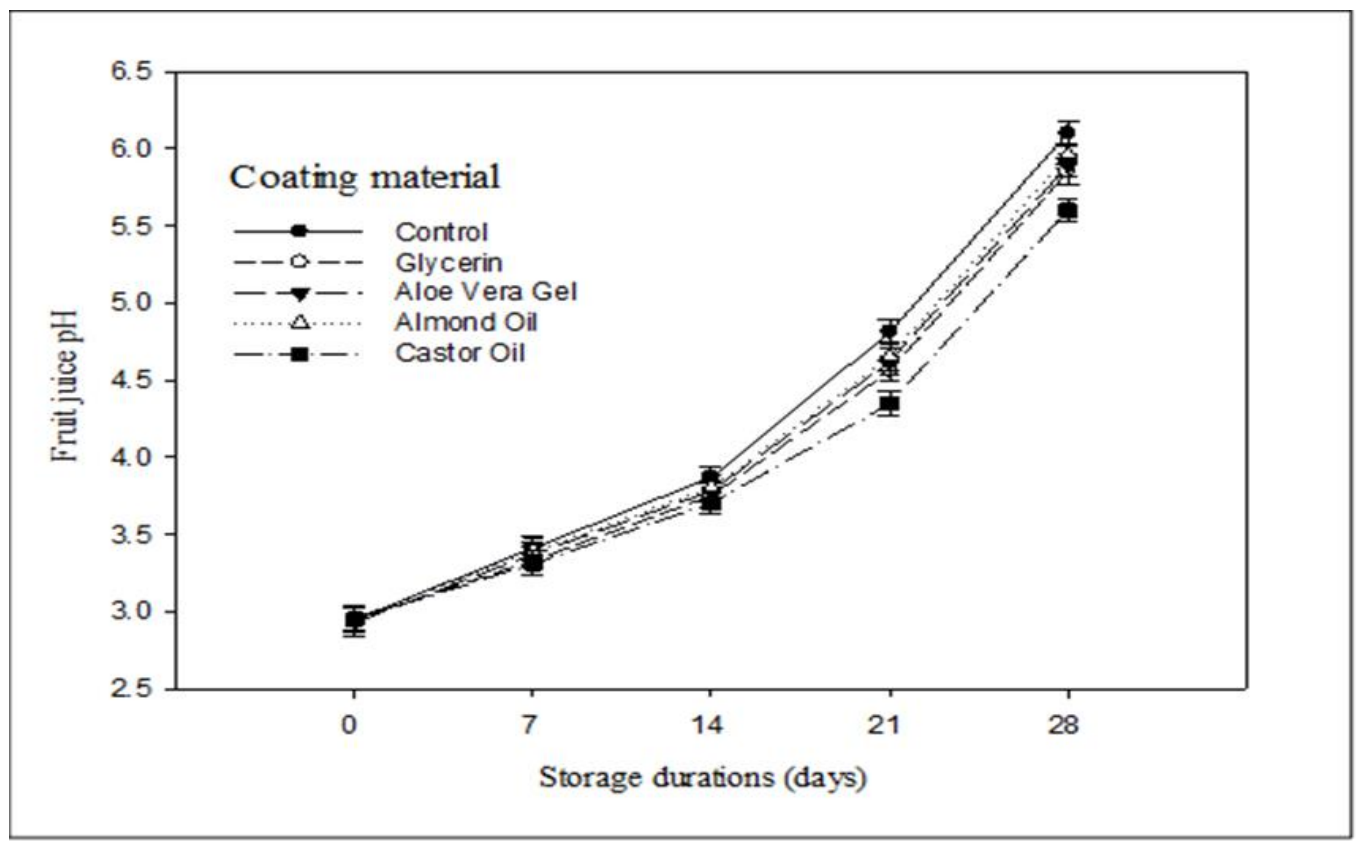

Figure 5. pH of fruit juice of Plum as affected by interaction of edible coatings and storage durations

\section{Fruit Firmness $\left({\left.\mathrm{kg} . \mathrm{cm}^{-2}\right)}^{-2}\right.$}

Different types of coatings, storing durations and its interaction importantly affected fruit firmness as presented in (Table 2). Fruits that were treated with glycerin, gave the highest fruit firmness having value of $3.78 \mathrm{~kg} . \mathrm{cm}^{-2}$, followed by almond oil treated plums $\left(3.67 \mathrm{~kg} \cdot \mathrm{cm}^{-2}\right)$. Although, the lowest fruit firmness i.e. $3.16 \mathrm{~kg} . \mathrm{cm}^{-2}$ was recorded in control fruits. Fruit firmness got declined as storing duration increased. The maximum 
firmness of fruit that was $4.40 \mathrm{~kg} . \mathrm{cm}^{-2}$ was noted on day 0 , followed by firmness of 3.57 value at 7 days storage, while the lowest fruit firmness i.e. $2.59 \mathrm{~kg} . \mathrm{cm}^{-2}$ ) was noticed in those kept for 14 days storage. Data regarding interaction indicated that maximum firmness of fruit i.e. $4.46 \mathrm{~kg} . \mathrm{cm}^{-}$ ${ }^{2}$ was observed in control and those treated with glycerin at storage of 0 day duration. Though, the lowest value of firmness of fruit that is $2.10 \mathrm{~kg} . \mathrm{cm}^{-2}$ was recorded in fruits that were untreated at storage time of 14 days (Fig. 6).

\section{Fruit color}

The results in (Table 2) disclosed that the maximum value of fruit color (7.31) was noted in castor oil covered plums, followed by those fruits that were treated with almond oil having color score value of 6.63, while those fruits that were untreated, revealed the least score color value of 5.41. The anticipated color value i.e. 9.33 was recorded for fruits kept at storage of 7 days, followed by those fruits which were kept stored for 0 day duration, though minimum score value of 3.60 was noticed in fruits with storage time of 28 days duration. The maximum color score value of 9.66 was noted in those fruits that were treated with castor oil at storage time of 7 days after the interaction of coatings and storage duration. Furthermore, the control fruits gave the minimum color value (1.83) after storage of 28 days' time (Fig. 7).

\section{Fruit taste}

The findings presented in (Table 2) depicted that fruits that were coated with castor oil, revealed 7.90 as the highest taste score value, while 7.23 taste score value was recorded for fruits having almond oil coating. The untreated fruits gave the lowest value for taste score i.e. 5.30. Concerning the storage time, the maximum taste score value of 9.33 was found in fruits with storage duration of 7 days, followed by 8.13 taste score value in those fruits that were kept at storage of 0 day time, whereas the minimum value i.e. 3.53 was noted for taste score at 28 days storage. Similarly, data regarding interaction between duration of storage and coatings explored a maximum value i.e. 9.66 for taste score stored at duration of 7 days in castor oil treated fruits, though a minimum value of taste score that is 1.50 was found in fruits that were kept controlled and stored for 28 days duration (Fig. 8).

Table 2. Juice content, fruit firmness, color, aroma score and taste score of plum fruit as affected by edible coatings and storage duration

\begin{tabular}{|c|c|c|c|c|c|}
\hline $\begin{array}{c}\text { Coating } \\
\text { Materials }\end{array}$ & $\begin{array}{c}\text { Juice content } \\
(\mathbf{\%})\end{array}$ & $\begin{array}{c}\text { Fruit firmness } \\
(\text { Kgcm-2) }\end{array}$ & Color score & $\begin{array}{c}\text { Taste } \\
\text { score }\end{array}$ & Aroma score \\
\hline Control & $57.60 \mathrm{c}$ & $3.16 \mathrm{e}$ & $5.41 \mathrm{~d}$ & $5.30 \mathrm{e}$ & $5.30 \mathrm{e}$ \\
\hline Glycerin & $59.53 \mathrm{~b}$ & $3.78 \mathrm{a}$ & $5.73 \mathrm{~d}$ & $5.90 \mathrm{~d}$ & $5.90 \mathrm{~d}$ \\
\hline Aloe vera Gel & $58.06 \mathrm{bc}$ & $3.37 \mathrm{~d}$ & $6.18 \mathrm{c}$ & $6.36 \mathrm{c}$ & $6.36 \mathrm{c}$ \\
\hline Almond oil & $58.40 \mathrm{bc}$ & $3.67 \mathrm{~b}$ & $6.63 \mathrm{~b}$ & $7.23 \mathrm{~b}$ & $7.23 \mathrm{~b}$ \\
\hline Castor oil & $63.40 \mathrm{a}$ & $3.61 \mathrm{c}$ & $7.31 \mathrm{a}$ & $7.90 \mathrm{a}$ & $7.90 \mathrm{a}$ \\
\hline LSD $\leq \mathbf{0 . 0 5}$ & 1.81 & 0.0 & 0.35 & 0.29 & 0.29 \\
\hline \multicolumn{5}{|c|}{ Storage duration (days) } \\
\hline $\mathbf{0}$ & $82.06 \mathrm{a}$ & $4.40 \mathrm{a}$ & $8.26 \mathrm{~b}$ & $8.13 \mathrm{~b}$ & $8.13 \mathrm{~b}$ \\
\hline $\mathbf{7}$ & $73.46 \mathrm{~b}$ & $3.57 \mathrm{~b}$ & $9.33 \mathrm{a}$ & $9.33 \mathrm{a}$ & $9.33 \mathrm{a}$ \\
\hline $\mathbf{1 4}$ & $62.53 \mathrm{c}$ & $2.59 \mathrm{c}$ & $6.11 \mathrm{c}$ & $6.70 \mathrm{c}$ & $6.70 \mathrm{c}$ \\
\hline $\mathbf{2 1}$ & $46.20 \mathrm{~d}$ & ----- & $3.96 \mathrm{~d}$ & $5.00 \mathrm{~d}$ & $5.00 \mathrm{~d}$ \\
\hline $\mathbf{2 8}$ & $32.73 \mathrm{e}$ & ----- & $3.60 \mathrm{e}$ & $3.53 \mathrm{e}$ & $3.53 \mathrm{e}$ \\
\hline LSD $\leq 0.05$ & 1.81 & 0.04 & 0.35 & 0.29 & 0.29 \\
\hline \multicolumn{7}{|c|}{ Interaction } \\
\hline C.M $\times$ S.D & $*$ Fig 5 & *Fig 6 & $*$ Fig 7 & $*$ Fig 8 & $*$ Fig 9 \\
\hline
\end{tabular}

Means followed by dissimilar letters differ each other by $5 \%$ level of significance 


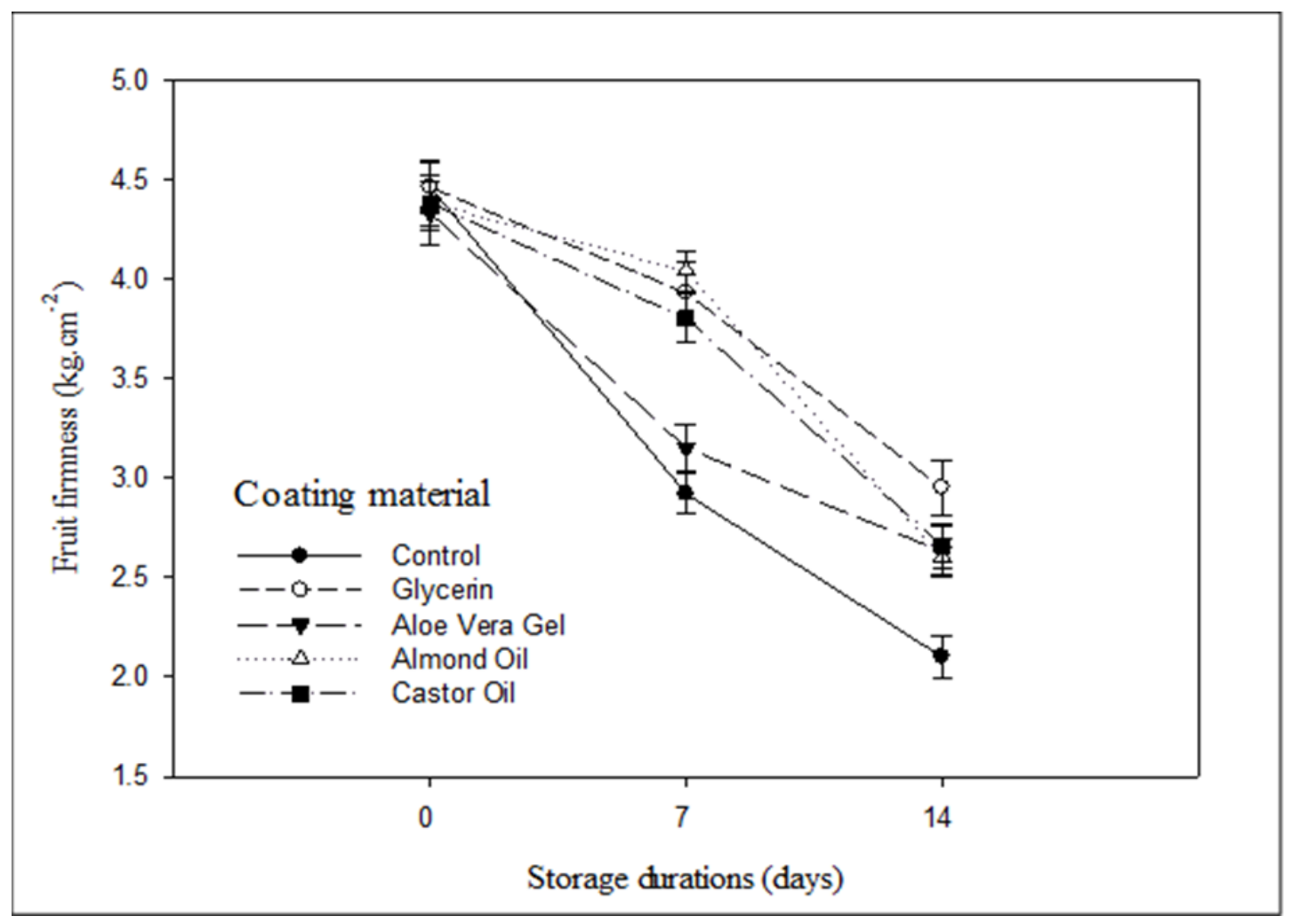

Figure 6. Fruit firmness of Plum fruit as affected by interaction of edible coatings and storage durations

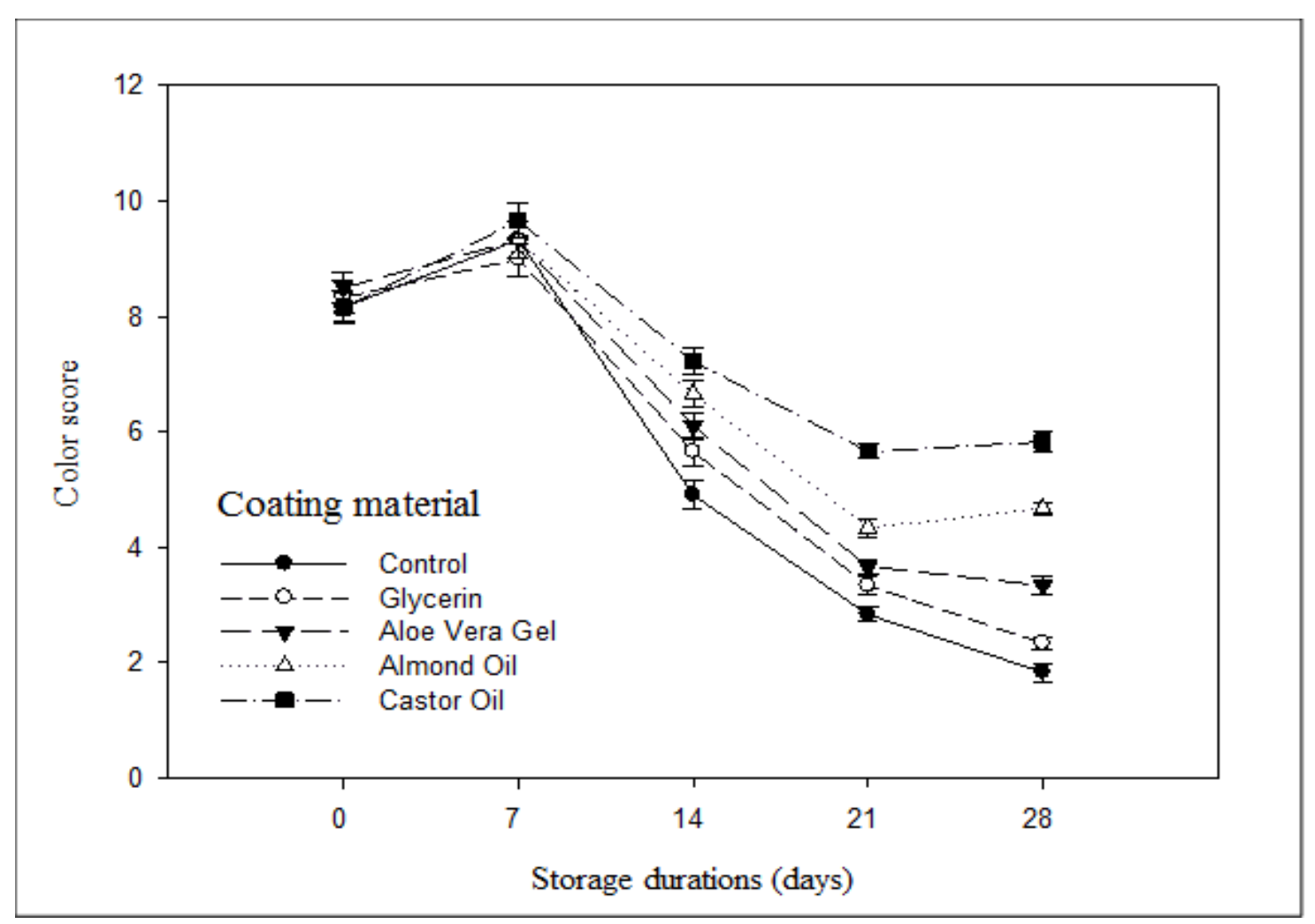

Figure 7. Fruit color score of Plum fruit as affected by interaction of edible coatings and storage durations 


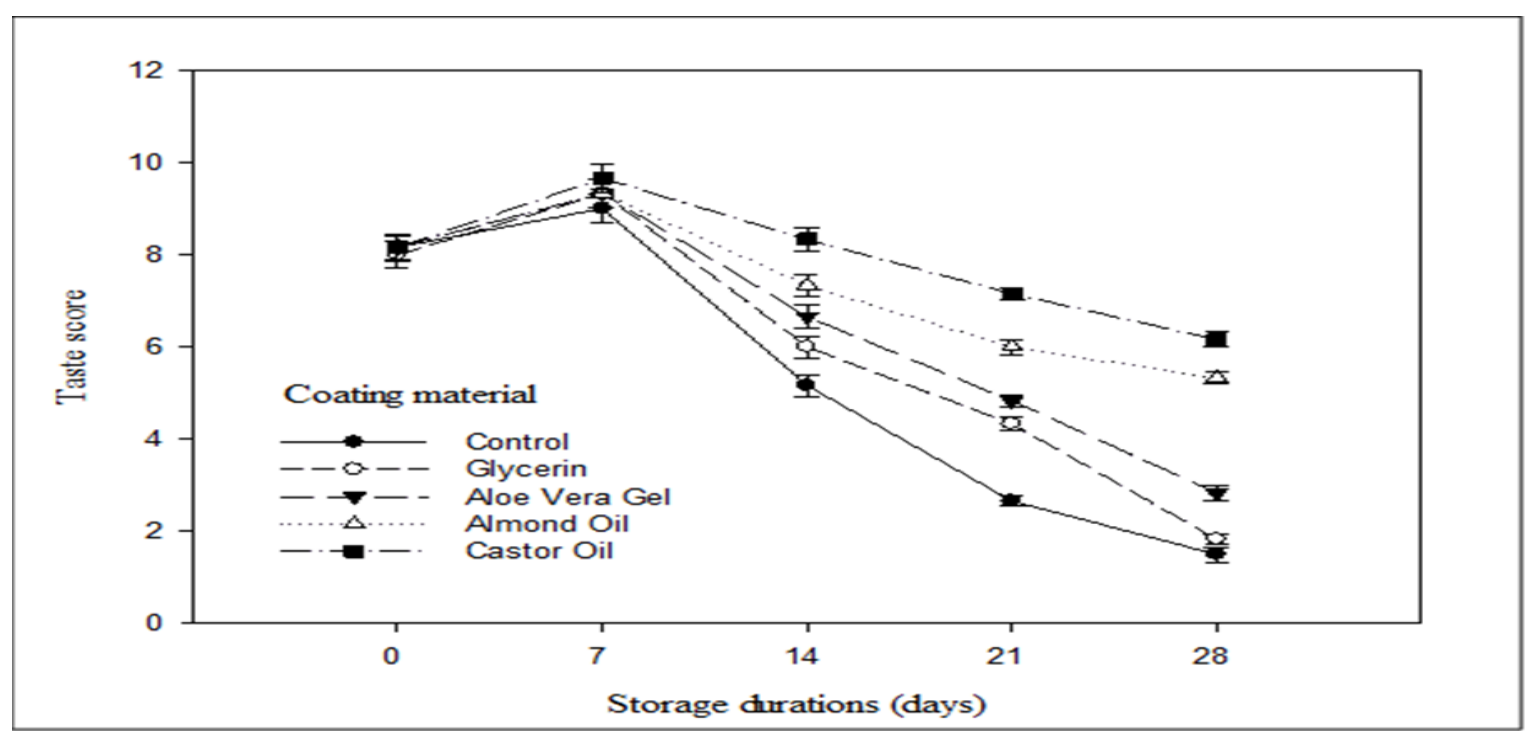

Figure 8. Fruit taste score of Plum fruit as affected by interaction of edible coatings and storage durations

\section{Fruit aroma}

Mean data related to the effect of coatings and storing durations on aroma of plum fruits is described in (Table 2) which disclosed that fruits coated with castor oil, revealed maximum score value of 7.90 for aroma, followed by aroma (7.23) of fruits treated with almond oil. The lowest value for aroma score i.e. 5.30 was recorded in the control fruits. The average data relating duration of storage time illustrated the maximum score value of 9.33 for aroma, stored for 7 days of duration, followed by score value of 8.13 for aroma of fruits kept at 0 time duration, while the minimum aroma score that is 3.53 was recorded at 28 days duration of storage. Additionally, studying interaction of various coatings and storage time showed that the maximum i.e. 9.66 aroma score value was noticed in fruits coated with castor oil kept stored for 7 days of duration, while in case of controlled fruits which were kept for 28 days of storage time, the minimum taste score value i.e. 1.50 was obtained (Fig. 9).

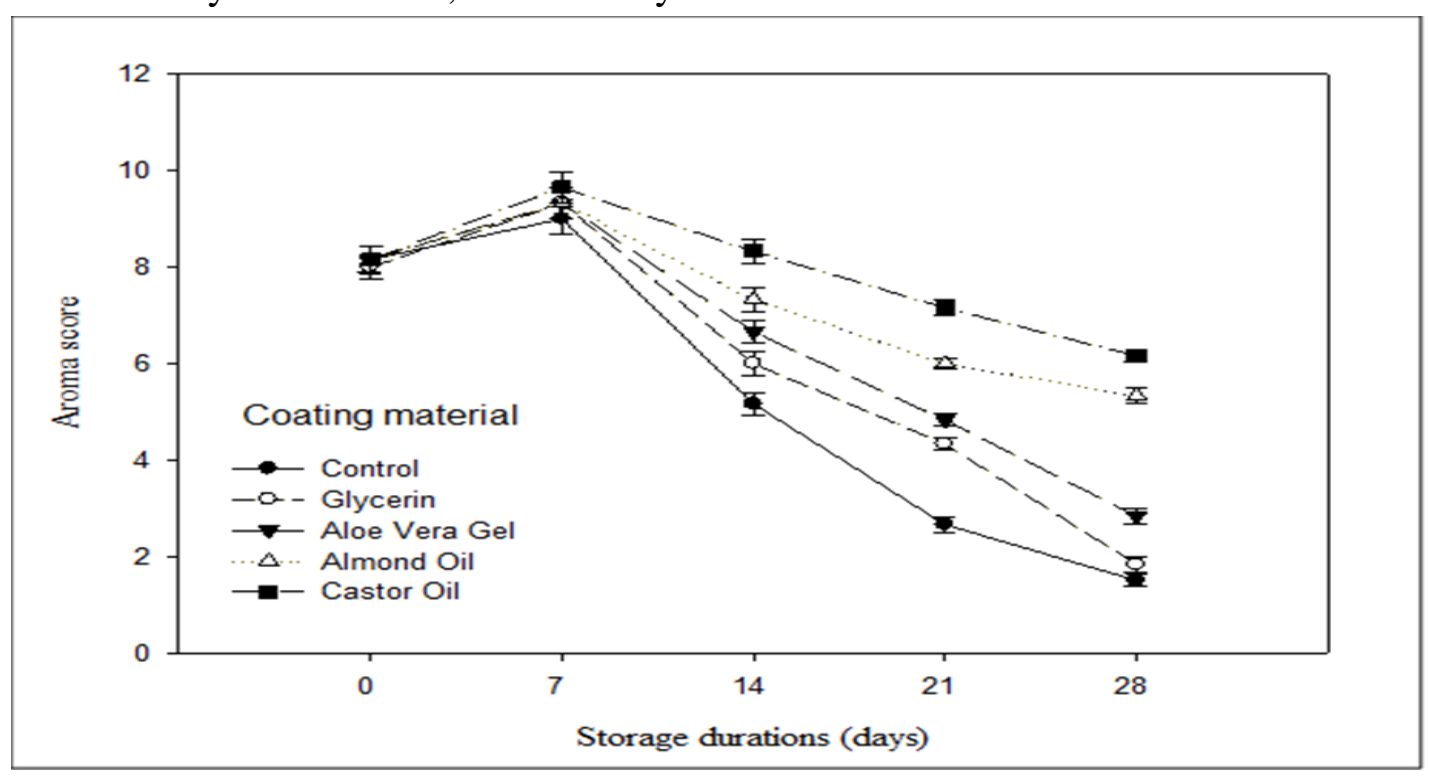

Figure 9. Fruit aroma score of Plum fruit as affected by interaction of storage durations and edible coatings 


\section{Discussion}

Transpiration, Respiration and other metabolic activities are the major factors causing weight loss occur in fruits and other horticultural produce [29]. This might be because of the reason that during the fruit ripening, cell wall degradation and membrane permeability caused the evaporation from the fruit surface. Also, with the phenomenon of water moment from inner cells to the outside atmosphere during transpiration in the form of water vapors. Findings of our research are in relation to Baldwin [30] who stated that fruit weight and water loss is protected easily with edible coating. Bisen et al. [31] noted a decrease in weight loss in Kagzi lime fruits treated with castor oil in comparison to the treated ones and control. Conversion of starch into sugar and hydrolysis of polysaccharides in cell wall cause an increase in storage duration which increases the TSS of fruits [30]. Rojas-Grau et al. [32] quoted the similar findings where they stated that by extending fruit ripening, postharvest respiration is reduced; in addition, it also reduces the phenomenon of starch transformation to sugars that is needed for sustaining the fruits' total soluble solid. TSS of fruits increases with high respiration and other metabolic activities and this may be because of proto-pectin's breakdown into pectic-substances, disaccharides and fructose into monosaccharides. Similarly, Kaundal et al. [33] also declared that rise in TSS and sugar level is caused due to increase in storage time. Furthermore, oils and fats have been studied containing large molecular mass, anti-microbial, anti-fungal as well as hydrophobic attributes act as a disease resistant in fruits which reduces the microbial attack [34]. According to Lin and Zhao [14], aloe vera gel contains various anti-biotic and anti-fungal compounds that may cause delay of microorganisms which act as disease causing agent in fruits and other produces. Similarly, results of our findings are in relation with those of Baldwin [17] who studied that aloe vera gel coated over grapes showed significant decrease of yeast and molds development, and diseases as well. Reducing effect of decay may be due to antimicrobial compounds present in aloe vera gel.

When duration of storage increases, titratable acidity reduces, because by prolonging the storage duration, the fruits organic acids are converted to soluble sugars and decomposed. As a result, acidity decreases while TSS and sugar increases [35]. During storage the fruit utilizes the acids so the acid in fruit is decreased [36]. Our study outputs are in accordance to the findings of Bai et al. [37] where they declared that respiration process and loss in water reduces by the use of coating. Coatings halts the gases exchange which causes accumulation of $\mathrm{CO}_{2}$ in fruit and during storage reduces acidity, it results in slow ripening process. Because of its low stability, the most challenging vitamin found to be preserved was ascorbic acid during storage, whereas, slow ascorbic acid reduction occurs because of the low temperature storage [38]. Decline was observed in content of ascorbic acid with the passage of time during storage times. Coatings resulted slowness in ripening process of fruit and therefore it retains the ascorbic acid content for a prolonged time [39]. Ascorbic acid is water soluble and for that reason it is depleted with the moisture loss. Castor oil coating retains ascorbic acid content by reducing water loss and retarding ripening process. Castor oil also adhere antioxidants which inhibits oxidation of the fruit and as a result retains the ascorbic acid content of fruit [40]. High respiration rate causes a remarkable rise in catabolic activities due to which organic acids breakdown and as a consequence $\mathrm{pH}$ level increases [26]. Various treatments' use change the biochemical status of fruits and also metabolic processes and respiration rate is reduced which are the reasons for $\mathrm{pH}$ 
change and there is rise in $\mathrm{pH}$ in the last storage periods because of the water vapors present in the pack that leads to saturation of the atmosphere of packs [41]. Our study outcomes are supported by Imran et al. [42] where they established that an increase in $\mathrm{pH}$ level happens as a result of the development of free acids and hydrolysis of pectin. Study shows that breakup of acids to sugars during respiration, $\mathrm{pH}$ of fruit was found increased. Our study findings are consistent with that of Bai et al. [37] that states that at storage the fruit itself utilizes the acids so the acids in the fruits depletes which in result enhances the $\mathrm{pH}$ of juice. Application of coatings of different kinds helps in sustaining the content of moisture in horticulture commodities and it also retains the content of fruit juice [43]. Same results were declared by Sumbali \& Munjal [40] who stated that fruit coatings are able to sustain the content water of fruits. Castor oil is not a drying oil as it has less reactivity towards air compared to other oils. This property gives it authenticity to retain water in the food commodity which eventually leads to retain juice content of the fruit [44]. Summu \& Bayindirli [45] declared that fruit firmness reduction is because of the oxygen existence which leads to the formation of de-hydro ascorbic acid gained from ascorbic acid. Similarly, transpiration occurs from the surface of fruits which reduces fruit firmness. Fruits are softened due to the insoluble proto-pectin degradation and breakdown into soluble pectins or it is due the cellular disintegration which leads to enhanced membrane permeability [46]. Our findings are supported by Asghar et al. [47] where they mentioned that the edible coating of glycerin and gum arabic shown good effect on shelf life improvement of peach fruits by enhancing quality features i.e. firmness, TSS, loss in weight as well as overall acceptability. Study outcomes are in harmony with the results of Herianus $e t$ al. [48] who declared that content ascorbic acid, color, aroma and taste of the fruit was maintained by coating. More color score was observed in fruits which were completely coated and it is because of low rate of respiration in these fruits and from surface of the fruit the colorful pigment is reduced thus the score of color is high. With extended duration of storage the color of fruit is reduced or lost because from fruit surface the colorful pigment vanishes [49]. Color improvement during storage is due to chlorophyll degradation of fruits and carotenoids and anthocyanin synthesis [50]. By the use of coatings the rate of fruit ripening is slowed down which leads to aroma, taste and color maintenance and it also extends the fruit commodity's shelf-life [51]. Against Oxygen, $\mathrm{CO}_{2}$, moisture and solute movement, coating act as a semipermeable obstacle, therefore the rate of respiration, alternative oxidation reaction and loss of water is reduced thus taste of fruit becomes acceptable to consumer [35]. In uncoated fruits the minimum score of tastes because of an-aerobic respiration which leads to more production of ethanol and it results in odd flavors [52]. Castor oil, contrasting to other vegetable oils, needs less or no deodorization; a process which eliminates the comparatively volatile contents which leads to unwanted colors, odors and flavors in commodities, so it retains all these quality attributes [53]. Bisen et al. [31] detected reduction in the value score of aroma on extended storage time who declares that fruits' skin possess oil glands that in a natural way releases specific flavors. Delay in the ripening process of fruits that were coated caused the maximum score for aroma and it sustains aroma for a prolonged time and then these fruits release a pleasant flavor [31].

\section{Conclusion}

By analyzing the study findings, it is established that castor oil coated fruits retained almost all quality parameters i.e. percent juice content, fruit firmness $\left(\mathrm{kg} . \mathrm{cm}^{-2}\right)$, ascorbic acid $\left(\mathrm{mg} .100 \mathrm{~g}^{-1}\right)$, 
titratable acidity (\%), total soluble solids ( ${ }^{\circ}$ Brix), $\mathrm{pH}$ of fruit juice, color, taste and aroma with minimum weight loss at control atmosphere of ${ }^{0} \mathrm{C}$, up to 28 days of storage. At storage, the fruits that were uncoated did not sustain all the quality aspects during the research investigation. Additionally, plum fruits may be coated with castor oil that could be stored for 28 days for sustaining its quality attributes at a control temperature of $8^{0} \mathrm{C}$ without much deterioration. Additional researches should be performed to examine the coating materials' impact mainly that of castor oil on quality features of plum fruits for 28 days storage interval.

\section{Authors' contributions}

Conceived and designed the experiments: M Sajid, Performed the experiment: A Basit \& Bashir M, Analyzed the data: A Basit \& ST Shah, Contributed materials/tools: I Ullah, I Ahmad, I Ahmad, MA Khalid, Sanaullah \& I Ullah, Wrote the article: A Basit, Reviewed/Edited the article: ST Shah \& Sanaullah, Supervised the experiment: M Sajid.

\section{References}

1. Khan D, Khan AR, Bibi S, Ali S \& Khalil IA (2007). Storage stability of persimmon fruits (diospyros kaki) stored in different packaging materials. J Agri Biol Sci 2(2): 20-23.

2. Saima N (2001). M.Sc. (Hons) Thesis. Quality improvement and shelf life extension of plum fruit. Horticulture Department. Khyber Pakhtunkhwa Agricultural University, Peshawar, Pakistan.

3. Liu FW (1990). Post-harvest handling of horticultural crops in Asia. Department of Horticulture, National Taiwan University.

4. Khan M, Rahim T, Naeem M, Shah MK, Bakhtiar Y \& Tahir M (2008). Postharvest economic losses in peach production in district Swat. Sarhad J Agric 24(4): 705-711.

5. Aujla KM, Abbas M, Mahmood K \& Saadullah S (2007). Marketing system of fruits, margins and export potential in Pakistan, Pakistan.
6. Chahal S \& Bal JS (2003). Effect of postharvest treatments and packaging on shelf-life of Umranber at cool temperature. J Res Punjab Agric Univ 40: 363-369.

7. Bisen A, Pandey SK \& Joushwa JE (2008). Effect of gamma irradiation, growth retardant and coatings on storability of lime fruits. Asian J Hort 25:159-163.

8. Basit A, Ayaz S, Rab A, Ullah I, Shah ST, Ahmad I, Ullah I \& Khalid MA (2019). Effect of stevia (Stevia Rebaudiana L.) leaf extract on the quality and shelf life of lemon (Citrus limon L.). Pure and Appl Biol 8(2): 1456-1468.

9. Turhan KN (2009). Is edible coating alternative to MAP for fresh and minimally processed fruits. 10th International controlled and modified atmosphere research conference. Antalya, Turkey pp 80-85.

10. Martinez-Romero D, Alburquerque $\mathrm{N}$, Valverde JM, Guillen F, Castillo S, Valvero D \& Serrano M (2006). Postharvest sweet cherry quality and safety maintenance by aloe era treatment a new edible coating. Post-harvest Biol. Technol 39(1): 93-100.

11. Falcao-Rodrigues MM, Moldao-Martins M \& Beirao-da-Costa ML (2007). DSC as a tool to assess physiological evolution of apples preserved by edible coatings. Food Chem 102: 475-480.

12. Sonti S (2003). Consumer perception and application of edible coatings on fresh-cut fruits and vegetables. MSc. Thesis. Osmania University, Hyderabad, India.

13. Wilson R, Schie V \& Howes BJ (1998). Overview of the preparation, use and biological studies on polyglycerol polyricinoleate (PGPR). Food \& Chem Toxicol 36(9-10): 711-8.

14. Lin D \& Zhao Y (2007). Innovations in the development and application of edible coatings for fresh and minimally processed fruits and vegetables comprehensive review. J Food Sci Food Saf 6: 60-71.

15. Kumar S \& Bhatnagar T (2014). Studies to enhance the shelf life of fruits using Aloe vera based herbal coating: A Review, Noida Int. Uni., Greater Noida, and U.P.

16. Dhall RK (2013). Advance in edible coating for fresh fruits and vegetables: A review. Cri Rev in Food Sciand Nutr 53(5): 435-450. 
17. Baldwin EA (1994). Edible coating for fresh fruits and vegetables: past, present and future. In : Krochta JM, Baldwin EA, Nisperos-Carreido MO (eds), Edible coating and films to improve food quality, Techonomic publishing company, Inc., Lancaster, Pennsylvania, USA. pp 25-64.

18. Undurraga PL Oleta JA \& Taito M (1995). Effect of N, O-carboxymethyl chitosan, and nutrisaveon Avocado fruits has during cool storage, Proceeding of the World Avocado Congress $3^{\text {rd }}$. pp 362-365.

19. Tharantharn RN (2003). Biodegradable films and composite casting: past, present and future, Trends in Food Science and Technology. 14(13): 71-78.

20. Ahmad M, Khattak MR, Jadoon SA, Rab A, Basit A, Ullah I, Khalid MA, Ullah I \& Shair M (2019): Influence of zinc sulphate on flowering and seed production of flax (Linum usitatissimum L.): A medicinal flowering plant. Inter J of Biosci 14: 464476.

21. Alam M, Hayat K, Ullah I, Sajid M, Ahmad M, Basit A, Ahmad I, Muhammad A, Akbar S \& Hussain Z (2020): Improving okra (abelmoschus esculentus 1.) Growth and yield by mitigating drought through exogenous application of Salicylic acid. Fres Environ Bulle 29: 529-535.

22. Basit A, Khan S, Sulaiman Shah S \& Shah AA (2019): Morphological features of various selected tree species on the greater university campus Peshawar, Pakistan. Inter J of Bot Stu 4: 92-97.

23. AOAC (2000). Official Methods of Analysis. The Association of the Official Analytical Chemist. 20th Ed. Arlington, USA.

24. Basit A, Hassnain, Alam M, Ullah I, Shah ST, Zuhair SA \& Ullah I (2020). Quality indices of tomato plant as affected by water stress conditions and chitosan application. Pure Appl Biol 9(2): 13641375

25. AOAC (2002). Association of Official Analytical Chemists. 17th edition. Washington, DC, USA: Association of Official Analytical Chemists.

26. Sajid M, Basit A, Ullah I, Tareen J, Asif M, Khan S, Ali QS, Gilani SAQ, Zeb S \& Nawaz MK (2019). Efficiency of calcium chloride $(\mathrm{CaCl} 2)$ treatment on post-harvest performance of pear (Pyrus communis L.). Pure Appl Biol 8(2): 1111-1125.
27. Rehman, S, Ahmad I, Ghafoor A \& Baloch AK (1982). Quality of sweet oranges as influenced by the fruit orientation on the tree. Pakistan J Sci 34: 65-70.

28. Basit A, Shah K, Rahman MU, Xing L, Zuo X, Han M, Alam N, Khan F, Ahmed I \& Khalid MA (2018). Salicylic acid an emerging growth and flower inducing hormone in marigold (Tagetes sp. L.). Pure Appl Biol 7(4):1301-1308.

29. Veravrbeke EA, Verboven P, Oostvelt P \& Nicolai BM (2003). Predication of moisture loss across the cuticle of apple (Malus sylvestrissup) during storage. Model simulations and practical applications. Postharvest Biol and Technol 30: 89-97.

30. Baldwin EA (1994). Surface treatments and edible coatings in food preservation. Handbook of food preservation. Sec. Ed. Retardation of Weight Loss and Surface Desiccation. pp 24-64.

31. Bisen A, Sailendra KP \& Neha P (2012). Effect of skin coatings on prolonging shelf life of kagzi lime fruits (Citrus aurantifolia Swingle). J Food Sci Technol 49(6): 753-759.

32. Rojas-Grau MA, Tapia MS, Carmona AJ \& Martin-Belloso O (2007). Alginate and gellan-based edible coatings as carriers of anti-browning agents applied on fresh-cut fuji apples. Food Hydrocolloid 27: 118127.

33. Kaundal GS, Mushtaq K, Minhas PS \& Bal JS (2000). Effect of growth regulators, nutrient and wax emulsion on the storage behavior of plum (Prunussalicina). J Res Ludhiana 37: 48-55.

34. Baloch MK, Bibi F \& Jilani MS (2011). Quality and shelf life of mango (Manngifera indica L.) fruit as affected by cooling at harvest time. Sci Hort 130(3): 642-646.

35. Singleton VL, Orthofer R \& Raventos RSL (1999). Analysis of total phenols and other oxidation substrates and antioxidants by means of Folin-Ciocalteu Reagent. Methods Enzymol 299: 152-178.

36. Bhattarai DR \& Gautam DM (2006). Effect of harvesting method and calcium on postharvest physiology of tomato. Nepal Agric Res J 7: 37-41.

37. Bai RK, Huang MY \& Jiang Y (1988). Selective permeability of chitosan-asetic 
acid complex membrane and chitosanpolymer complex membrane for oxygen and carbon dioxide. Polym Bull 20: 83-88.

38. Akhtar A, Abbasi NA \& Hussain A (2010). Effect of calcium chloride treatments on quality characteristics of loquat fruit during storage. Pak J Bot 42(1): 181-188.

39. Park HJ (1999). Development of advanced edible coatings for fruits. Trends Food Sci Technol 10: 254-260.

40. Sumbali M \& Munjal K (1980). Recent advances in the management of fungal pathogens of fruit crops. The Maharaja sayajirao University of Baroda, India. pp 6-7.

41. Elham Z, El-Motty A \& El-Faham SY (2013). Effect of oil coating and different wrapping materials on prolonging storage periods of florida prince peaches fruits. $J$ of Appl Sci Res 9(4): 2927-2937.

42. Imran A, Khan R \& Ayub M (2000). Effect of added sugar at various concentration on the storage stability of guava pulp. Sarhad J Agric 16(1): 89-93.

43. Robertson J, Meredith F, Horrat R \& Senter S (1990). Effect of cold storage and maturity on the physical and chemical characteristics and volatile constituents of peaches (Cv. Cresthaven). J Agric Food Chem 38: 620-624.

44. Thomas A (2005). Fats and fatty oils. Ullmann's Encyclopedia of Industrial Chemistry. Weinheim. pp 173.

45. Summu G \& Bayindirli L (1995). Effects of sucrose polyester coating on fruit quality of apricots. J Sci Food Agric 67: 537-540.

46. Mattoo AK, Murata T, Pantastico EB, Chachin K, Ogata K \& Phan CT (1975).
Chemical changes during ripening and senescence in post-harvest physiology handling and utilization of tropical and subtropical fruits and vegetables. Pantastico E.B. (Ed.). AVO Publication, Westport, Connecticut. pp 103-27.

47. Asghar A, Alamzeb, Farooq, Qazi IM, Ahmad S, Sohail M, Islam MS \& Shinwari AS (2014). Effect of edible gum coating, glycerin and calcium lactate treatment on the post-harvest quality of peach fruit. Iiste 30: 2224-6088.

48. Herianus JD, Singh LZ \& Tan SC (2003). Aroma volatiles production during fruit ripening of Kensington Pride mango. Postharvest Biol Technol 27: 323-336.

49. Ribeiro C, Vzicente AA, Teixeira JA \& Miranda C (2007). Optimization of edible coating composition to retard strawberry fruit senescence. Postharvest Biol Technol 44: 63-70.

50. Zhu X, Wang Q, Cao J \& Jiang W (2008). Effects of chitosan coating on postharvest quality of mango (Mangifera indica L. cv. Tainong) fruits. J Food Process and Preser 32(5): 770-784.

51. Dang KTH, Singh Z \& Swinny EE (2008). Edible coatings influence fruit ripening, quality and aroma biosynthesis in mango fruit. J Agric Food Chem 56:1361-1370.

52. Guire MC (1997). Market quality of guava after hot water treatment and application of carnauba wax coating. Hort Sci 32: 271-2.

53. Vinay RP, Dumancas G, Viswanath LK, Maples R \& Sunbong BJ (2016). Castor oil: properties, uses, and optimization of processing parameters in commercial production. J Insights 9: 1-12. 